\title{
Impacts of Solid Waste Management Practices on Environment and Public Health: A Case Study Wadajir District in Benadir Region of Somalia
}

\author{
Ibrahim Abukar Shegow and Atanga Desmond Funwie* \\ Department of Environmental Science, Kesmonds International University, USA \\ *Corresponding author
}

Ke y w o r d s
Solid waste
management, Public
health,
Environment,
Dumpsite,
Incineration
Article Info
Accepted:
17 June 2020
Available Online:
10 July 2020

\section{Keywords}

Solid waste health,

Environment,

Dumpsite,

Article Info

Accepted:

17 June 2020

10 July 2020

\section{A B S T R A C T}

With urbanization being experienced in the word, there is significant rise in the amount of solid waste generated at the households' leading to insatiable consequence to the human health and the environment. There is now an acknowledgement on the impacts of poor solid waste management (SWM) practices on the natural and human environment. This work aimed to study the environmental and public health impacts of solid waste management taking a case study of Wadajir district specifically in the Benadir region of Somalia, investigating the sources, types and impacts of solid waste management practices, examine and assess the disposal options and their impacts on public health and the environment. The study collected data from a systematic random sample of 30 households selected from the study area using questionnaires. The research used both qualitative and quantitative methods for data analysis using SPSS version 25 on which various analytical operations were performed, including generation of percentages and descriptive statistics. It was found that the environment in the study area has been highly polluted with solid wastes from poor households handling practices. The solid waste generated in the household consisted of organic food materials (68.6\%), plastics (28.6\%) and polythene bags $(2.9 \%)$. These resulted in health problems such as diseases (cholera, dysentery, typhoid, malaria and dengue fever) and environmental degradation. Burning and dumpsite were selected as the preferred methods of disposal because they are easy to use, convenient and cheap. With regard to waste collection, private firms and youth groups have been helping the community, collecting waste at least one and twice a week at an affordable fee. The study results support the test hypothesis that household waste type influences waste management practices. The study concluded that households and commercial organizations should have storage receptacles; demarcate land for use as dumpsites while engaging community participation in promoting waste management. The study recommended policies and by-laws relating to waste collection and disposal in the region, reducing waste management through waste management value chain and establishment of properly constructed landfill site at a suitable location in Benadir region. 


\section{Introduction}

Solid waste management and disposal has been a worldwide concern which most countries are battling with and trying to find best solutions of dealing with (Alkaateb and Yakubu, 2013; Laner et al., 2012). Waste is defined as unwanted remains, residues discarded and material or by products which are no longer required by the initial user. These materials are by-products of human activities such as process of preparation, manufacture, packing, repacking, unpacking, construction, renovation of structures and mining operations. Almost any substance that is discarded is designated as waste (Hoornweg et al., 2012).

Rapidly growing populations, rapid economic growth and rise in community living standards have accelerated the generation rate of this Municipal Solid Wastes (MSW), causing their management to be a bigger challenge worldwide (Seo et al., 2004). City experiencing rapid population growth and development in all sectors of life and resultant change in land use patterns have the biggest challenge in handling their solid wastes. With high level of development, the issues of mismanagement and deterioration in solid waste generation and disposal are hiking (Mohsin and Chinyama, 2016; Owusu, 2010).

Proper solid waste disposal is a vital component of environmental sanitation and sustainability. A sustainable environment and improved waste management offers opportunities for income generation, health improvements and reduced vulnerability. This could hardly be attained in some of the developing countries such as Somalia (Wilson et al., 2006).

In many developing countries, scavengers of slums especially women and children are actively engaged in collection and recycling of solid waste material informally. This is a successful way of earning a living and has a great potential to bring improvement in solid waste management sector if authorities pay a special focus (Muhammad and Manu, 2013). Thus, the valuable stuff from the scavenged material turn the scavenging fairly a paying enterprise for the poor people of the cities e.g. slum dwellers and street urchins (Aljaradin $e t$ al., 2015).

Indiscriminate disposal of solid wastes can presents direct or indirect effects on the environment and the public health generally. The effects of improper solid wastes disposal activities are widely recognized issue as cited by many related studies such as (Christensen et al., 2003).

The environmental and public health impact of poor solid waste disposal is not fully understood (Wilson et al., 2006; Pate, 2012). Many health impact of poor solid wastes disposal depends on the type of exposure, nature of the waste, disposal site proximity. Common environmental impact includes contamination of underground water quality, emission of odor, breeding places of insects, such as flies, mosquitoes and dumping rodents.

Managing solid waste improperly poses threat to the health of individuals and the environment. If these wastes are not disposed in a proper way, they create breeding places for insects such as flies, mosquitoes as they provide food and harborages for rats. These insects and rats are health risk in that they are potential disease transmitters (Yemaneh et al., 2017). Improper solid waste management contaminate the environment, causes all types of pollution, contamination of water sources etc., according to United State Public Health Service identifies 22 human diseases that are linked to improper management of municipal solid wastes (Pervez, 2013). 


\section{Materials and Methods}

\section{Study area}

This study was carried out in Wadajir district, one of the 16 districts in Benadir region, Mogadishu Somalia and the second largest district in the region. Geographically, it lies on the South western part of Mogadishu, being established in 1970s. The district houses The Somali National University, the former US embassy which is now a refugee camp called Siliga Amerkankaanfd the former Jaalle Ziyad Military Academy, now called AMISOM Brunidan Contingent.

The area has an estimated population of about 300,000 people by District Authority (DA) and more than $40 \%$ of the people are internally displaced people (IDPs). The district has four sub-districts which include Timacade, General Daud, Xalane and HawoTako.

\section{Research design}

The research used a case study which adopted the qualitative and quantitate methods. The quantitative methods was used to obtain data in frequencies and percentages whereas qualitative methods was used to collect detailed data that contributed to an in-depth understanding of the extent of solid waste management practices in Wadajir district in Benadir region. A cross sectional descriptive study using survey methods, structural questionnaires was designed and pre-tested together with other field observations.

\section{Data collection}

Primary data was collected through a field survey in the study area during March 2020.

A structured questionnaire was used for primary data collection from 30 respondents selected by simple random sampling. Respondents consisted of both male and female having corresponding share of $40 \%$ and $60 \%$.

This entailed data from solid waste management practices, sources of solid wastes, methods of solid waste disposal, effects of solid waste management on the environment and public health. Primary data was collected through household and institutional surveys through administering questionnaires, conducting interviews and by observation.

Secondary data was acquired from the relevant literatures and related documents, books, published and unpublished written materials, thesis, dissertations, journals, articles and reports. Data on solid waste management practices will be obtained from the state of environment reports from the national government archives.

\section{Data analysis}

Raw data was entered in Excel and later Statistical Package for Social Science (SPSS) version 20 for analysis. Appropriate summary tables, graphs, charts and summarized information generated were then used to enhance the descriptions.

The acquired data consisted of mostly quantitative attributes. Simple descriptive statistics were used to analyze the responses regarding solid waste types, main sources of waste generation, their impact on surrounding environment and the resultant diseases and problems caused by the solid waste. The quantitative data like for demographic and social economic characteristics, solid waste generated, disposal options, impacts on the environment and public health were summarized using descriptive statistics namely mean, frequencies and percentages. 


\section{Results and Discussion}

\section{Socio-demographic characteristics of the respondents}

Table 1 below indicates that majority $(56.7 \%)$ of respondents were female while their counterpart representing $43.3 \%$. In regard to age, the highest percentage was between the age bracket of 31-40 years at $36.7 \%$ followed by $(33.3 \%)$ of $21-30$ years of age, $(13.3 \%)$ of above 50 years, and (3.3\%) were below 20 years. With regard to the education level, majority of respondents $(40 \%)$ had attained the secondary education level, with $10 \%$ having gone up to primary level, $(6.7 \%)$ with post-secondary and (10\%) were graduates. It was worth noting that $20 \%$ of the respondents did not attend to any formal education in the study area.

The results illustrated how conscious the older people are with regards to waste management as compared to respondents who were in the age of below 20 years of age. The older respondents cared more about their environments as compared to the younger people. Further the younger respondents consumed twice as older respondents mainly because of different lifestyles.

With regard to the education level, similar findings were recorded by Kumar et al., (2014) who found out that $38.3 \%$ of the respondents had studied up to secondary school $28.0 \%$ had studied up to primary school and $4.0 \%$ were illiterate. In his study on households' Demand for Better Solid Waste Disposal Services in Ghana, Alhassan and Mohammed (2013) indicated that the most significant and influencing factors that affect solid waste management in any given area are the environmental safety concern of the respondent, level of satisfaction of current waste disposal services, education level, household size, length of stay in the current residence, walking time to public dumpster, and sex of respondent.

\section{Understanding of solid waste}

It was so worrying that majority of the respondents in the study area had no clear understanding of what solid waste management was. This poor understanding encouraged the problems of solid waste management. The perception of the respondents towards solid waste management is a key entity for the sustainable management of the household wastes. The significance of this understanding is that people on the ground will be taking stringent measures that will ensure a clan and a healthy environment. Studies by Otchere et al., (2014) reported that a proper understanding of what sustainable waste management is plays a key role in how the waste is collected, transported and disposed. From the study results, it is clear to note that all the definitions of what solid waste management is lies in the definition as described by UNEP (2013; Hoornweg et al., 2012). It is expected that from the understanding, the community should be channel their attention to a cleaner and healthy environment, which is contrary to the findings in the study area.

\section{Sources and types of solid waste in Wadajir district}

A clear appreciation of the quantities and characteristics of the solid waste being generated in the homesteads is a key component in the development of efficient and cost-effective solid waste management strategies. The survey results collected in the study area demonstrated that about $51.52 \%$ of the solid waste was produced by slaughter houses, followed by industries as well as markets $(39.39 \%)$. These categories are in the alignment of the study by Martin (2000) who categorized solid waste into three major categories i.e. household (residential) refuse, 
institutional wastes, street sweepings, commercial areas wastes, as well as construction and demolition debris. In developing countries, these wastes also contain various amounts of industrial wastes from small scale industries.

It is quite unfortunate that the data on solid waste management in Benadir region is unrealistic which is rarely available for the actual generation of solid wastes. The results indicated that the high volume of solid waste was mixed up. Among the interviewed respondents, $68.6 \%$ stated that the solid waste they generated contained organic food materials, while plastics were at $28.6 \%$ and polythene bags at $2.9 \%$.

\section{Solid waste collection}

According to the interviewed respondents, it was reported that $70 \%$ of the solid waste was collected by privately owned firms, while the registered youth groups accounted for only $6.7 \%$. The remaining percentage was no accounted for by the researcher. The collected waste was transported by trucks and donkey cart to the designated dumpsites which are far from the study area. The absence of the government authority is worrying because this work is done by privately owned organization. A study by Awomeso et al., (2010) alluded that improper solid waste collection and disposal are common problems experienced in developing cities.

Table.1 Socio-demographic characteristics of the respondents

\begin{tabular}{|l|l|l|}
\hline Variable & Frequency & Percentage (\%) \\
\hline 1. Gender & & \\
\hline Female & 17 & 56.7 \\
\hline Male & 13 & 43.3 \\
\hline Total & 30 & 100 \\
\hline 2.Age & & \\
\hline < 20 years & 1 & 3.3 \\
\hline 21-30 years & 10 & 33.3 \\
\hline 31-40 years & 11 & 36.7 \\
\hline 41-50 years & 3 & 10.0 \\
\hline > 50 years & 4 & 13.3 \\
\hline Total & 29 & 96.7 \\
\hline 3.Education & & \\
\hline None & 6 & 20.0 \\
\hline Primary & 3 & 10.0 \\
\hline Secondary & 12 & 40.0 \\
\hline Post-secondary & 2 & 6.7 \\
\hline Graduate & 3 & 10.0 \\
\hline Total & 26 & 86.7 \\
\hline 4.Occupation & & \\
\hline Unemployed & 15 & 50.0 \\
\hline Employed & 11 & 36.7 \\
\hline Self-employed & 4 & 13.3 \\
\hline & & \\
\hline
\end{tabular}


Table.2 Sources of solid wastes

\begin{tabular}{|l|c|c|c|}
\hline Type of solid waste & Slaughter house & Industry & Market \\
\hline Organic waste & 9 & 2 & 2 \\
\hline Metal & 4 & 3 & 2 \\
\hline Polythene & 3 & 2 & 4 \\
\hline Plastics & 1 & 5 & 5 \\
\hline Total & $\mathbf{1 7}$ & $\mathbf{1 3}$ & $\mathbf{1 3}$ \\
\hline
\end{tabular}

Figure.1 Understanding of solid waste management

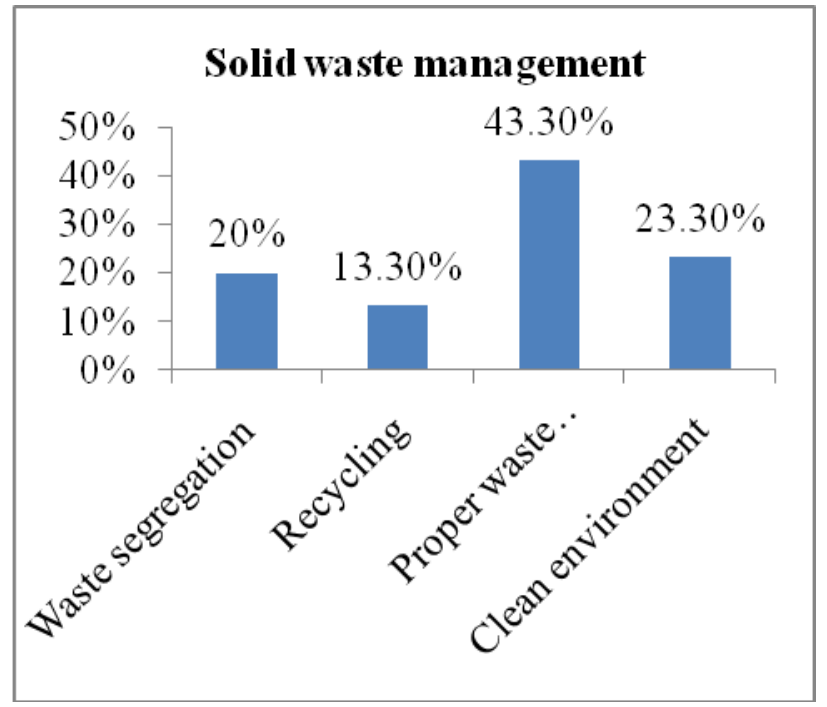

Figure.2 Types of solid waste

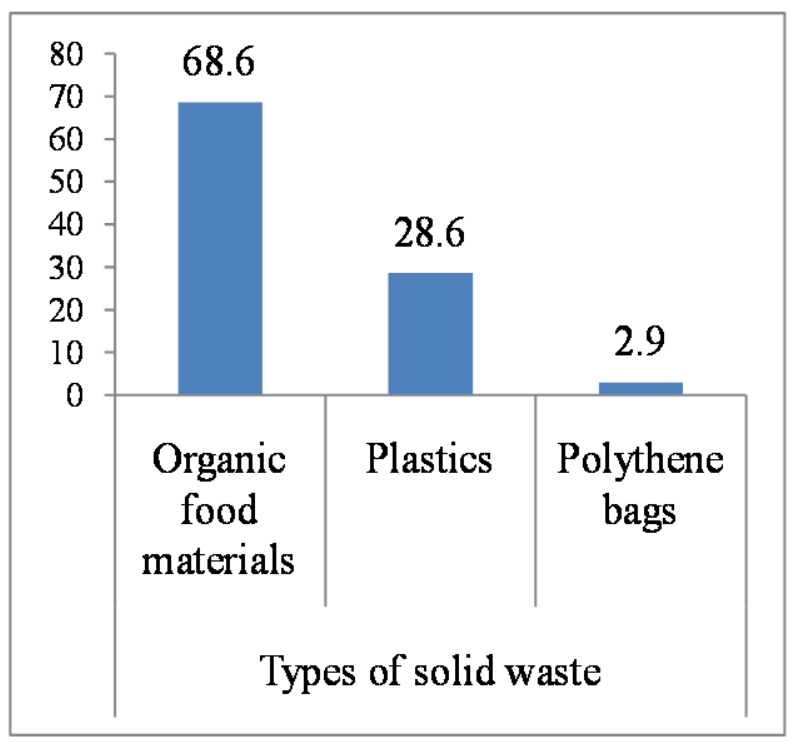


Figure.3 Waste disposal methods

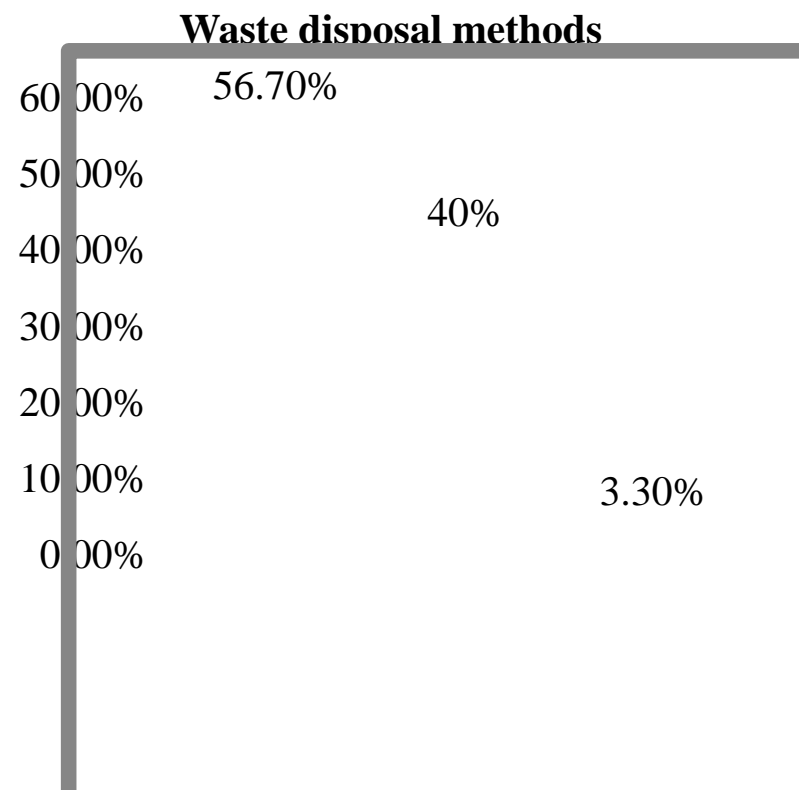

Figure.4 Diseases caused by poor solid waste disposal

\begin{tabular}{|c|c|}
\hline & Cholera \\
\hline & Typhoid \\
\hline $7.3 \%$ & Dysentery \\
\hline & Malaria \\
\hline & Fever \\
\hline $27.3 \%$ & \\
\hline
\end{tabular}

$18.2 \%$

$12.7 \%$

Diseases caused by poor solid waste disposal

The frequency of waste collection in the study are does not match the rate of generation. It was recorded that waste is collected once and twice a week at $43.3 \%$ and $33.3 \%$ respectively. Very few people pay for the waste collection services. The results indicate that there is dire need to bring change and the attitudes of the residents regarding the threats associated with open throwing of waste material. 


\section{Solid waste disposal methods}

Waste disposal is one of the most important management practices which need to be carefully planned. With regard to waste disposal at Wadajir district, the study identified that almost all solid waste generated in households is indiscriminately disposed together i.e. there is no habit of sorting organic from inorganic waste at the household level. Huge amount of organic materials comes from the rural areas depraving nutrients from the rural soil to feed the urban population, the leftovers after consumption have no way to return to the source to build the soil, rather lost and create problems to human health and the surrounding environment in the city due to mismanagement.

In this study, the results indicate that there is dire need to bring change in the attitudes of the residents regarding the threats associated with open throwing of waste material. Previous studies found that people living habits, household income, family size, level of educational attainment, religious and cultural beliefs, and social and public attitudes highly influence the generation and disposal of solid waste (Hamer, 2018).

Impacts of solid waste management on the environment and public health

There are impending risks of improper solid wastes handling to the environment and public health. The key health threats are considered to be indirect and awakened from the spread of disease by the vectors, as most untreated waste is dumped into the streets and stagnated there without being collected. This untreated waste provides breeding ground for insects, mosquitoes and flies. Direct health risks concern mainly the workers who are in direct contact with the waste that need to be protected, as far as possible. Uncontrolled hazardous wastes from industries mixing up with municipal wastes create potential risks to human health.

The key factors resulting to poor solid waste management in the region as listed by the respondents were; poor infrastructure, lack of proper segregation mechanisms, improper waste collection, insufficient dumpsites and financial constraints.

A study carried out in Wadajir district indicated that $77.1 \%$ of diseases in the area emanate from poor solid waste handling. Similar findings were reported by Khan et al., (2014) who found out that there is a relationship between improper solid waste disposal and the occurrence of vector-borne disease. Cholera, typhoid and dysentery are among the major diseases reported in the study area (Figure 3). Malaria was another threat to the community members. This was emanating form the mosquito bites which are harbored in solid waste heaps ad stagnant water.

Similar studies by Laner et al., (2014) also point out the problems of improper solid waste disposal and management related that have caused environmental and health risks.

In conclusion, this study was meant to address environmental and health problems associated with solid poor solid waste management in Wadajir district, Benadir region of Somalia. Accordingly, solid waste management in general and waste handling in particular was very poor. There was a challenge of solid waste segregation, collection, reuse, recycling, composting and disposal. The study concluded that the for a proper and adoption of sustainable solid waste handling, collection and disposal, the consciousness of the community members need to be raised through environmental awareness, capacity building and inculcation on the sustainable 
practices on waste management. Environmental literacy and environmental management skills have been shown to have a small but detrimental impact on recycling attitudes may not have resulted in recycling if knowledge about it was poor.

Physical and infrastructural capabilities lacking in the study area in relation to waste management, emerged to be very low. Communal solid waste disposal and burning appeared to be the most preferred method of solid waste management system in the study area. This is exacerbated by insufficient proper storage receptacles and long distance designated dumping sites. The issues of no waste reuse in most households make a huge contribution to large waste generation, none of which is collected by private service providers and youth groups.

No-availability of land properly selected and demarcated for uses dump site resulted in all manner of improper disposal, inhabitants still practice improper disposal from nearby bush to open dumps due to lack of enforcement of regulatory policies and programs irrespective of income levels.

\section{References}

Akaateba, M. A., and Yakubu, I. (2013). Householders' satisfaction Towards Solid Waste Collection Services of Zoomlion Ghana Ltd In Wa, Ghana. European scientific journal, 9(32).

Alhassan, M., and Mohammed, J. (2013). Households' Demand for Better Solid Waste Disposal Services: Case Study of Four Communities in the New Juaben Municipality, Ghana. Journal of Sustainable Development, 6(11), 16.

Aljaradin, M., Persson, K. M., and Sood, E. (2015). The role of informal sector in waste management, a case study; Tafila-Jordan. Journal of Resources and Environment, 5(1), 9-14.

Birhanu, Y., and Berisa, G. (2015). Assessment of
Solid Waste Management Practices and the Role of Public Participation in Jigjiga Town, Somali Regional State, Ethiopia. International Journal of Environmental Protection and Policy, 3(5), 153-168.

Chithra, K., Anilkumar, P. P., and Naseer, M. A. (2016). Municipal Solid Waste Management, a Major Impacted Sector of Urban Environment due to Residential Land Use Activities-Study of Kozhikode City. Procedia Environmental Sciences, 35, 110118.

Hamer, G. (2003). Solid waste treatment and disposal: effects on public health and environmental safety. Biotechnology advances, 22(1-2), 71-79.

Han, Z., Ma, H., Shi, G., He, L., Wei, L., and Shi, Q. (2016). A review of groundwater contamination near municipal solid waste landfill sites in China. Science of the Total Environment, 569, 1255-1264.

Hoornweg, D., and Bhada-Tata, P. (2012). What a waste: a global review of solid waste management (Vol. 15, p. 116). World Bank, Washington, DC.

Khan, A. A., Fatima, M., and Khan, K. (2014). Spatial analysis of environmental health risks: A case of Bahawalpur district, Pakistan. Pakistan Journal of Commerce and Social Sciences (PJCSS), 8(1), 238-257.

Kiran, K. G., Kini, S., Ravi, K., Santhosh, N. P., and Kiran, N. U. (2015). KAP study of solid waste disposal of households in Kuttar and Manjanadi Panchayath covered under gramaskhema programme of KS Hegde Medical Academy. Nitte University Journal of Health Science, 5(3), 29.

Laner, D., Crest, M., Scharff, H., Morris, J. W., and Barlaz, M. A. (2012). A review of approaches for the long-term management of municipal solid waste landfills. Waste management, 32(3), 498-512.

Mengistie, B., and Baraki, N. (2010). Community based assessment on household management of waste and hygiene practices in Kersa Woreda, Eastern Ethiopia. Ethiopian Journal of Health Development, 24(2).

Mohsin, M., and Chinyama, A. (2016). Impacts of Solid Waste Management Practices on Environment and Public Health: A Case of 
Bahawalpur City, Pakistan. Sciences, 9, 6979.

Mwanthi, M. A., Nyabola, L. O., and Tenambergen, E. (1997). Solid waste management in Nairobi City: Knowledge and attitudes. Journal of Environmental Health, 60(5), 23.

Narayana, T. (2009). Municipal solid waste management in India: From waste disposal to recovery of resources?. Waste management, 29(3), 1163-1166.

Otchere, A. F., Sarpong, K. O., and Okyere, S. (2014). Assessing the Challenges Affecting Solid Waste Management System in the Kumasi Metropolis. Journal of Arts and Humanities, 3(2), 50-63.

Owusu, G. (2010). Social effects of poor sanitation and waste management on poor urban communities: a neighborhood- specific study of Sabon Zongo, Accra. Journal of Urbanism, 3(2), 145-160.

Periou, C. (2012). Waste: the challenges facing developing countries-world production of municipal solid waste, 2012-2025. Private Sector and Development, 1(15), 1-6.

Pires, A., Martinho, G., and Chang, N. B. (2011). Solid waste management in European countries: A review of systems analysis techniques. Journal of environmental management, 92(4), 1033-1050.

Seng, B., Fujiwara, T., and Seng, B. (2018). Suitability assessment for handling methods of municipal solid waste. Global Journal of Environmental Science and Management, 4(2), 113-126.
Seo, S., Aramaki, T., Hwang, Y., and Hanaki, K. (2004). Environmental impact of solid waste treatment methods in Korea. Journal of environmental engineering, 130(1), 81-89.

Sharma, S. (2010). Awareness about Bio-medical waste management among health care personnel of some important medical centers in Agra. International Journal of Environmental Science and Development, $1(3) ; 251-255$.

Songsore, J., and McGranahan, G. (1993). Environment, wealth and health: Towards an analysis of intra-urban differentials within the Greater Accra Metropolitan Area, Ghana. Environment and Urbanization, 5(2), 10-34.

Uriarte, F. A. (2008). Solid Waste Management: Principles and Practices: an Introduction to the Basic Functional Elements of Solid Waste Management, with Special Emphasis on the Needs of Developing Countries. UP press.

Wilson, D. C., Velis, C., and Cheeseman, C. (2006). Role of informal sector recycling in waste management in developing countries. Habitat international, 30(4), 797-808.

Yemaneh, Y., Abera, T., Hailu, D., Niguse, W., Chewaka, L., Daniel, T., ... and Tsegaye, N. (2017). Knowledge Attitude and practice towards solid and liquid waste Management among Addis ketema and Kometa kebele community Mizan-Aman town, Bench-Maji zone, South Nations Nationalities and Peoples Regional State, South West Ethiopia, 2017. Journal of Environmental Geology, 1(1).

\section{How to cite this article:}

Ibrahim Abukar Shegow and Atanga Desmond Funwie. 2020. Impacts of Solid Waste Management Practices on Environment and Public Health: A Case Study Wadajir District in Benadir Region of Somalia. Int.J.Curr.Microbiol.App.Sci. 9(07): 2005-2014. doi: https://doi.org/10.20546/ijcmas.2020.907.230 